\title{
GENERAL ECOLOGY AND VASCULAR PLANTS OF THE HAZEN CAMP AREA*
}

\author{
D. B. O. Savile
}

\section{General description}

$\mathbf{H}^{2}$ Azen Camp, at $81^{\circ} 49^{\prime} \mathrm{N} ., 71^{\circ} 18^{\prime} \mathrm{W}$., lies on a small sandy point on the northwest shore of Lake Hazen, in northeast Ellesmere Island. Lake Hazen stands at $158 \mathrm{~m}$. above sea-level, extends $78 \mathrm{~km}$. ENE to WSW, and has a maximum width of $11 \mathrm{~km}$. It lies at the northern edge of a plateau bounded on the south by the Victoria and Albert Mountains and on the north by the United States Range. The Garfield Range, a southern outlier of the United States Range, extends to within $4 \mathrm{~km}$. of Hazen Camp. The high mountain ranges and icefields, with extensive areas over $2000 \mathrm{~m}$., and smaller hills effectively protect the land about Lake Hazen from incursions of unmodified cold air, and induce a summer climate that is very exceptional for this latitude. On the other hand the lake itself is large enough to keep air temperatures adjacent to the shore appreciably below those prevailing a few kilometres away.

The geology of northeastern Ellesmere Island has recently been described by Christie (1962). The lowlands at Hazen Camp are underlain by Mesozoic and Permian sediments, mainly sandstone and shale. These sediments outcrop conspicuously on Blister Hill (altitude $400 \mathrm{~m}$.), 1.5 to $2.7 \mathrm{~km}$. west of the camp; and on a series of small but steep foothills running southwest to northeast along a fault and passing 2.5 to $3 \mathrm{~km}$. northwest of the camp. These rocks weather rapidly. Consequently sand and clay in varying proportions are plentiful in the camp area. Immediately beyond the foothills Mt. McGill, closest peak in the Garfield Range, rises to $1000 \mathrm{~m}$. The mountains of this range consist of relatively resistant rocks of Silurian age, which shatter by frost action into boulders or slabs but do not readily weather into fine particles. Consequently large areas of the south-facing talus slopes are arid, with the summer runoff well below the surface. Day (in prep.) will discuss the soils of the Hazen Camp area.

The valley of Lake Hazen was overrun by Wisconsin ice, as numerous landforms indicate; and terraces show the water-level to have stood some $60 \mathrm{~m}$. above the present lake for a considerable time during deglaciation.

*Contribution No. 366 from the Plant Research Institute, Research Branch, Canada Department of Agriculture, Ottawa, Ontario. An investigation associated with the program "Studies in Arctic Insects". Entomology Research Institute, Canada Department of Agriculture (Paper No. 12). 


\section{Summer climate and weather}

In this discussion temperatures are given in Fahrenheit, to allow ready comparison with other North American stations, but Celsius equivalents are given for key figures. The double scale in Fig. 1 also serves as a rough conversion table.

When Hazen Camp was opened as an IGY station, detailed weather records were kept from August 21, 1957 to August 10, 1958 (Jackson 1959). Since that time there has been no winter occupation of the camp, but summer surface records were kept in 1961, 1962 and 1963. Extremely low winter temperatures have been recorded, owing to pronounced and persistent inversions at the lake surface. However, these winter extremes have little if any effect on the survival of plants and terrestrial invertebrates, whose every cell must be frozen even at temperatures $30^{\circ} \mathrm{F}$. above the minimum of $-68.5^{\circ} \mathrm{F}$. $\left(-55.8^{\circ} \mathrm{C}\right.$.) recorded in 1958.

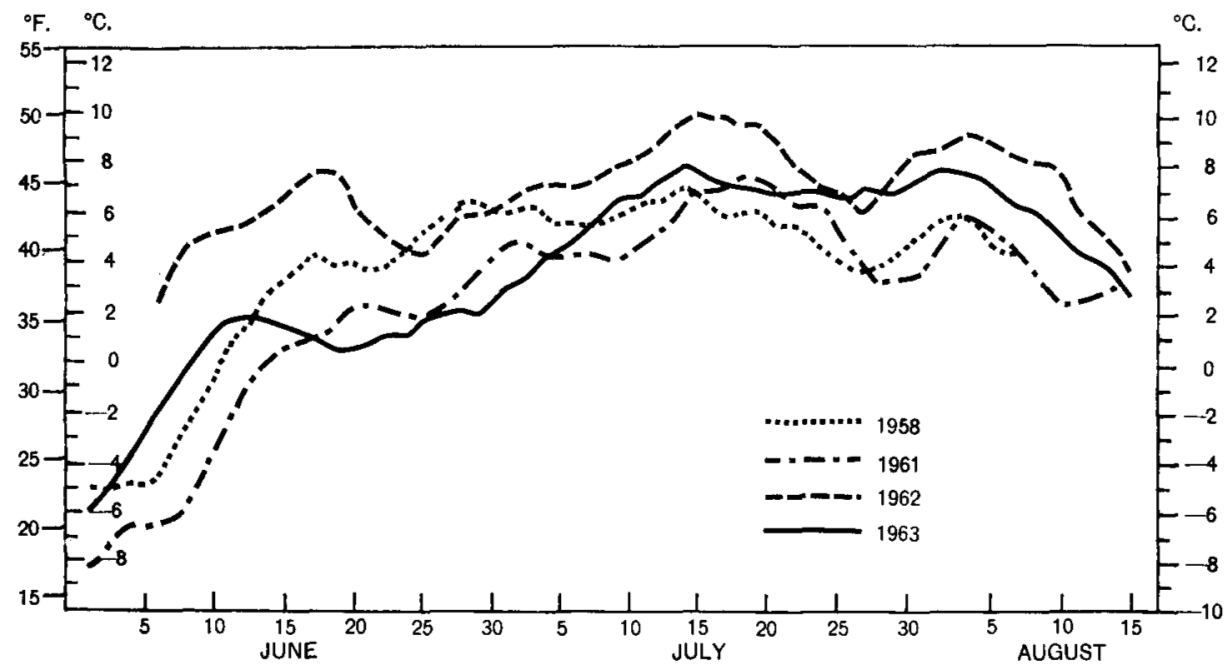

Fig. 1. Seven-day running mean summer air temperatures at Hazen Camp.

The summer temperatures vary considerably from year to year, but are generally exceptionally high for the latitude, higher in fact than for many coastal stations 5 to $8^{\circ}$ farther south. The four-years record of the July mean temperature, a convenient rough guide to growth potential, shows a range from $42.4^{\circ} \mathrm{F}$. in 1961 to $46.7^{\circ} \mathrm{F}$. in 1962 (average $44.2^{\circ} \mathrm{F}$.). The means for June range from 31.1 to ca. $40^{\circ} \mathrm{F}$. $\left(40.9^{\circ}\right.$ for June 3 to 30 , 1962) and those for August 1 to 15 from 40.8 to $45.6^{\circ} \mathrm{F}$. Thus the true July mean at the thermometer screen, roughly $100 \mathrm{~m}$. from the lake, is probably about $44^{\circ}$ F. $\left(6.7^{\circ}\right.$ C. $)$. Even when, as in 1962, Lake Hazen becomes completely ice-free it retains a substantial amount of ice until early August, and the surface remains very cold. It is believed that this large body of 
water appreciably modifies the summer temperature along its shores, and that dry sites about $2 \mathrm{~km}$. from it at the same altitude may have summer temperatures as much as $2^{\circ} \mathrm{F}$. higher than are recorded at Hazen Camp. In $1962 \mathrm{D}$. R. Oliver maintained a thermograph, checked daily against a thermometer, in a Stevenson screen near pond 34 (F 9) $1.8 \mathrm{~km}$. from the lake. Although this site is $60 \mathrm{~m}$. above the camp, and the screen stood in a wet sedge meadow, whereas the one at the camp is on dry sand, the temperature at this site was generally fully $1^{\circ} \mathrm{F}$. above that at the camp (D. R. Oliver, pers. comm.). It may also be noted that in 1962 the first flowering date for Saxifraga oppositifolia at Hazen Camp was June 7, but that Dr. G. Hattersley-Smith found it in flower southeast of the lake, on the Ruggles River, on June 2. A substantial lake influence is also suggested by the occurrence and early maturity of various plants high on the slopes of Mt. McGill, discussed below under boulder talus and springy slopes.

Data presented by Savile (1961) and Savile and Parmelee (1964) allow some comparison with the summer climate of other high-arctic stations.

Fig. 1 epitomizes the temperature trends by presenting 7-day running means for the four summers of record. It may be noted that the running mean was above $40^{\circ} \mathrm{F}$. for 32 days in 1961 , the coolest summer recorded, and for 68 days in the very warm summer of 1962. Despite the marked difference in mean temperatures from year to year, the pattern of temperature trend is surprisingly constant. The maximum occurs between July 14 and 18. It is followed by a pronounced and regular trough late in the month, and a marked secondary peak between August 1 and 3. There is also a weak and variable peak between June 12 and 20, followed by a poorly defined trough. A few random checks suggest that these characteristic fluctuations do not occur at other northern stations. Their causes are unknown. It is not clear whether this temperature pattern has an appreciable biological signifcance. Most arctic insects and cryptogamic plants seem capable of a gradual development, making some growth when conditions permit but being able to halt their activity at any stage with impunity (Downes 1962, Savile 1963). Flowering plants must generally, probably always, complete their fruiting cycle in a single season, but the perennial habit allows some unsuccessful seasons to be endured. However, some activities, such as insect flight, are governed more by a critical temperature than by a total heat requirement. It is thus possible that mating flights and pollination may be affected to some extent by this temperature pattern. The reader must, however, be warned against placing undue reliance upon these smoothed curves. Even during the trough periods an hour or two of sunny, windless weather may permit great activity by insects.

Soil temperatures were studied extensively in 1958 by Powell (1961). The maximum temperature of the soil surface on sunny days was generally 15 to $30^{\circ} \mathrm{F}$. higher than the air temperatures, and 5 to $10^{\circ}$ higher on overcast days. On sunny days minima were 5 to $10^{\circ} \mathrm{F}$. higher than, and on overcast nearly equal to air minima. 
The spread between air and soil-surface temperatures is governed chiefly by sunshine, wind and soil moisture. Incomplete data suggest that, from June 1 to August 15, Hazen receives somewhat over 50 percent of the maximum possible insolation. Few arctic stations record sunshine, but this figure is probably unusually high. Wind velocity, based on the averages of observations every 3 hours, averages barely $5 \mathrm{mi} . / \mathrm{h}$. $(2.25 \mathrm{~m} . / \mathrm{sec}$.$) ,$ approximately half that for most coastal stations, although strong winds occur occasionally. Summer precipitation is very low, ranging from 0.09 to 0.74 in. ( 2 to $19 \mathrm{~mm}$.) between June 1 and August 15; considerably less than that for Eureka, the most arid meteorological station in the Canadian Arctic. Thus the ground surface at Hazen Camp receives ample insolation, is cooled little by turbulent mixing of the air, and suffers relatively little evaporative cooling.

Data are lacking for summer temperatures of air 0 to $15 \mathrm{~cm}$. above the soil surface, a zone embracing much plant and insect activity; but low wind velocities suggest that the temperature gradient is less steep than at more exposed stations. This conclusion is supported by observations on insect activity and the fact that shelter does not promote plant growth to the degree observed at Isachsen and Resolute.

Relative humidity records for 1962 and 1963, based on observations every 6 hours, indicate a mean figure of 80 to 88 per cent in June, and 76 to 80 per cent in July and the first half of August. These figures are similar to available data for Eureka, but substantially lower than for most high-arctic stations.

As shown in the next section, aridity is far more important than temperature as a limiting factor in plant growth in most habitats in the vicinity of Lake Hazen. Indeed, the rather low breeding-bird density for a region of such elevated summer temperature (Savile and Oliver 1964) suggests that aridity distinctly limits the total biomass production on land.

\section{Principal habitats}

Although occasional excursions ranged $12 \mathrm{~km}$. or more from camp, the area studied in some detail ranged from the Snow Goose River delta to slightly beyond Blister Creek delta, and from the lake shore to approximately the crest of $\mathrm{Mt}$. McGill, some 25 to $30 \mathrm{~km}^{2}$. The accompanying sketch map (Fig. 2) shows the major habitats in this area. It is feasible to show only habitats that cover a substantial area. Some of the individual pond and marsh sites used for entomological studies are described in more detail by Oliver and Corbet (in prep.). Unless otherwise noted the observations recorded below are based on my records and collections made in 1962. In this discussion some individual habitats are referred to by their co-ordinates in Fig. 2. A few ecologically significant mosses are mentioned below; but because I am unable to recognize most species in the field, a full record of the species taken at any site would, from its incompleteness, be of negligible value. 


\section{Sand}

Little clean sand occurs except just east of the peak of Blister Hill (J 10) at 300 to $330 \mathrm{~m}$. Here Carex maritima occurs in typical form, accompanied by struggling plants of Stellaria spp., Arenaria rubella, Salix arctica and rarely other species.

Extensive, slightly muddy sand occurs between Blister Hill and the Camp (L-M 11). It is washed down from two large gullies on the hill by a vernal stream that passes close to the camp. There is an active blowout, up to $1.5 \mathrm{~m}$. deep, adjacent to the stream bed. The most actively moving sand bears little but Oxyria digyna and Draba bellii, except along the watercourse where Salix arctica and Luzula spp. occur. Although strong winds are uncommon at Lake Hazen, slight sand movement occurs frequently with moderate breezes. A windstorm on July 13, 1962, with a peak gust of 36 mi./h. (16.2 m./sec.), deposited fully $12 \mathrm{~mm}$. of sand on Dryas clumps in the lee of the blowout, and up to $40 \mathrm{~mm}$. behind Salix clumps along the watercourse. A prolonged gale on July 23, with a peak gust of $50 \mathrm{mi} . / \mathrm{h}$. $(22.5 \mathrm{~m} . / \mathrm{sec}$.$) , caused more severe movement, limited only by the bed$ being scoured down to a stable muddy crust. Silt and fine sand in other areas were lifted by this gale into clouds visible at a great distance, and deposits a few millimetres thick were noted in several places at the bases of slopes where eddies occurred. Sand and silt also blew over a cut-bank near the lake before the snow melted, as was indicated by peculiar labyrinthiform deposits noted on the vegetation in mid June when the snow had just melted.

Appreciable sand also occurs on beach ridges, especially on Blister Creek delta, but it is generally mixed with silt or gravel.

\section{Gravel}

Dry gravel occurs most conspicuously along the summit of Blister Hill, which is composed largely of weathered sandstone. It supports only a few xerophytes such as Saxifraga tricuspidata, Poa glauca, and the deep-rooted Erysimum pallasii. Moister gravel, generally mixed with sand and silt, occurs on low parts of Blister Creek delta, and supports especially Poa abbreviata, Arenaria rubella, Saxifraga oppositifolia, and Epilobium latifolium. A few small gravel knolls occur on the plain northeast of camp (Q8, R5, S5), generally supporting stunted plants of Saxifraga tricuspidata, Erysimum pallasii and Potentilla chamissonis, and rarely such scarce species as $P$. vahliana or Androsace septentrionalis.

\section{Clay plains and slopes}

Little pure clay occurs, but there are abundant deposits with a clay content high enough to cause baking and cracking. Plains and shallow slopes that are not noticeably saline (e.g., U5, V6) may have a cover of only 1 to 5 per cent but composed of various species, including Oxyria digyna, Salix arctica, Potentilla spp. (especially chamissonis), Poa glauca, $P$. hartzii, Lesquerella arctica, Erigeron compositus, and Lychnis triflora. 
Cut banks are generally moister and, if stable, more richly vegetated (e.g., N8). South-facing banks may have the above species in greater profusion and also Taraxacum spp. especially arctogenum, Braya spp., Draba spp., Agropyron latiglume, Calamagrostis purpurascens, and Stellaria spp. The moss Polytrichum hyperboreum occurs on several rather sandy slopes with appreciable moisture. North-facing banks, which receive less effective insolation despite potential daily sunshine of 24 hours, may have a closed cover of Poa arctica, Alopecurus alpinus, Papaver radicatum, Salix arctica, and traces of other species.

\section{Saline clay}

In areas that show a superficial crust of salts there may be little but scattered clumps of Puccinellia angustata. Such areas, inadequately irrigated by runoff from adjacent hills, are true desert, with an appearance suggestive of the badlands of North Dakota or eastern Montana. One such site (N7) bore abundant clumps of Puccinellia angustata arising from the cracks between the polygons, and of well-grown $P$. poacea arising from the centres of the polygons. Dr. Oliver noted the same distinction in 1963; and the large size of many clumps of both grasses suggests that the individual polygons must last for many years.

\section{Dryas hummocks}

When Dryas integrifolia occurs in nearly pure stands, as it may over wide areas, it usually forms hummocks $10 \mathrm{~cm}$. or more in height, with the intervening spaces bare or with scattered lichens. Although the term Dryas tundra is conveniently used in a loose sense, pure Dryas does not generally form a closed cover. At or near the bases of slopes, where snow drifts into the cracks and, with fluctuating temperatures, considerable ice-wedging may occur, the hummocks are generally much larger, occasionally $60 \mathrm{~cm}$. high. Slightly moist hummocks frequently bear Pedicularis capitata, especially on their margins. Those on east or southeast slopes frequently have the sides clothed with Cassiope tetragona, which probably demands the moisture supplied by drifted snow and may benefit from the protective snow cover. Cassiope was not found in other situations. The soil underlying the hummocks generally contains considerable clay but always with abundant coarser particles.

\section{Dryas - Kobresia tundra}

When Dryas occurs with Kobresia myosuroides, which is abundant on dry south slopes, an essentially closed cover is sometimes achieved. When this occurs the hummocks are generally small or occasionally absent. It is not certain whether the closed cover reduces existing hummocks or only prevents their formation. Observations of small but actively growing colonies of Carex rupestris among Dryas hummocks on level ground suggest that this sedge, by unifying ground cover and insolation, actually reduces the hummocks. 


\section{Dryas - Salix tundra}

This association, generally with small amounts of several other species, occupies an appreciable area of the higher part of Blister Creek delta; but it is unimportant elsewhere in the area.

\section{Muddy delta}

Parts of the deltas of Blister Creek and Snow Goose River, especially low-lying peripheral areas, are of fine muddy silt. The richest parts have more than 75 per cent cover. Whether the cover is scanty or nearly complete its makeup varies greatly both within and between sites. The lack of fixed associations seems due partly to the slight biological competition existing when the cover is sparse (Savile 1960); and partly to the instability of these sites and the fact that the streams, in flood, bring down seeds or plants that generally grow in quite different habitats. For example, Cerastium alpinum, which was generally found on relatively dry lowland slopes; $C$. arcticum, largely confined to rather moist talus at 600 to $750 \mathrm{~m}$; and $C$. beeringianum, usually seen along marshy streams, all occur together on the delta mud.

The Snow Goose delta bears much Carex aquatilis var. stans and Eriophorum scheuchzeri, with small amounts of Juncus biglumis, Equisetum arvense, $E$. variegatum, and a few scattered grasses.

Some muddy parts of the Blister Creek delta resemble those of the Snow Goose delta; but other parts, with 75 per cent or more cover, bear much Epilobium latifolium; appreciable Dryas integrifolia, Salix arctica, Draba spp., Stellaria spp., Cerastium spp., Lychnis apetala, Arenaria rubella, Papaver radicatum, Saxifraga oppositifolia, Braya purpurascens, Juncus biglumis, Poa abbreviata, Colpodium vahlianum and Deschampsia brevifolia; and odd plants of Saxifraga caespitosa and Cochlearia officinalis. The richness of this area seems to be due to the fact that, despite the marked fluctuation in stream flow, with mid to late summer flooding, it suffers neither extreme aridity nor flooding severe enough to cause serious erosion. The worst of the flood is diverted through other channels.

\section{Gravel delta}

This habitat intergrades with the last, but, where fully developed, it is distinctive. The coarse gravel areas are subject to desiccation in early summer, followed by violent flooding in mid to late summer. Plant cover ranges from nil to about 50 per cent. It consists predominantly of Epilobium latifolium, with a little Dryas, Papaver, Salix and Saxifraga oppositifolia; and rarely, in low, moist areas, Cerastium beeringianum and Arenaria rossii. The coarse gravel grades into boulders with no vegetation or occasionally a little Epilobium latifolium.

\section{Boulder talus}

The slopes of Mt. McGill are clothed mainly with coarse, steep, highly unstable boulder talus. The slopes are in part very sterile through instability 
and superficial aridity, in part sparsely vegetated with, especially, Salix arctica, Saxifraga tricuspidata, and $P o a$ glauca, and occasionally, in springy areas, richly vegetated. The southeast slope of the mountain immediately west of Blister Creek is almost uniformly of coarse boulders and very arid. The moister talus slopes are ecologically important because they harbour various species at 600 to $850 \mathrm{~m}$. that are scarce or absent below: Cerastium arcticum, Silene acaulis var. exscapa, Cardamine bellidifolia, Saxifraga flagellaris ssp. platysepala, S. nivalis, S. rivularis, S. tenuis, Potentilla hyparctica, and Erigeron eriocephalus. A few other plants are restricted to the talus slopes but grow down to $450 \mathrm{~m}$., e.g., Woodsia glabella, Cystopteris fragilis, and Arnica alpina spp. angustifolia. The continuously moist slopes bear various bryophytes, which are all scarce or absent in the lowlands; Distichium capillaceum, Tortula ruralis, Philonotis tomentella, Orthothecium chryseum, and Hypnum revolutum occurred repeatedly; and Bryum caespiticium, B. cryophilum, Bartramia ithyphylla, Timmia austriaca, Campylium stellatum, Polytrichum alpinum, P. juniperinum, Arnellia fennica, and Clevea hyalina were found once.

The talus slopes supply nearly all breeding sites for the Hoary Redpoll (Acanthis h. hornemanni) and many for the Snow Bunting (Plectrophenax n. nivalis), thus appreciably influencing the breeding-bird density (Savile and Oliver 1964).

The early maturation of plants on the south slopes is remarkable. By July 14, 1962 Salix arctica at 600 to $700 \mathrm{~m}$. was completely mature, the capsules were splitting and the foliage was yellow. Plants near the camp at about $160 \mathrm{~m}$. did not reach this condition until about July 28. This early development seems to be due partly to strong spring insolation on the steep south slopes, and partly to the slopes being about $4 \mathrm{~km}$. from the cooling influence of Lake Hazen.

Continuously available moisture without flooding unquestionably is largely responsible for various mesophytes occurring predominantly on the talus slopes. The almost negligible summer precipitation causes an abrupt transition from marsh to arid ground. Thus moist talus slopes offer the best habitat for moist-mesophytic species with a tolerance for low temperatures. Of species that also occur regularly in the lowlands, it may be noted that Alopecurus alpinus and Papaver radicatum, known from their vigorous growth on the central plateau of Somerset Island to tolerate low temperatures (Savile, 1959), were taller at $600 \mathrm{~m}$. than at almost any lowland site. Papaver radicatum, Saxifraga caespitosa, S. cernua, and $S$. oppositifolia were common at $900 \mathrm{~m}$.; and Cardamine bellidifolia, which demands abundant moisture, was plentiful at the highest wet site studied, at $850 \mathrm{~m}$. Luzula nivalis, Saxifraga nivalis, and $S$. rivularis were among other species found high on Mt. McGill. Thus almost all the species that were found on the Somerset plateau or near the limit of growth for vascular plants at $150 \mathrm{~m}$. altitude on Ellef Ringnes Island (Savile 1961), and that are therefore adapted to cold moist mesic sites, are to be found nearly to the top of Mt. McGill, and their partial absence from the uppermost $50 \mathrm{~m}$. must be attributed to lack of moisture rather than to low temperature. 


\section{Springy slopes}

A major peculiarity of the Hazen Camp area, attributable to the adjacent mountains, is the marked fluctuation in the water table of slopes and marshes directly connected with the mountains. These areas are briefly moistened by the generally light snow cover melting in spring, then, especially in seasons such as 1962, quickly become superficially dry again. Most of these slopes were already dry in mid June 1962 and remained so until early July, causing the water table to fall markedly in many marshes. Run-off due to retreating permafrost in the talus slopes increased in July until most of the springy slopes were completely flooded. They are dominated by Eriophorum triste, with smaller amounts of Arctagrostis latifolia, Polygonum viviparum, and Juncus biglumis; and they occasionally support a little Equisetum arvense, E. variegatum, Carex aquatilis var. stans, Juncus albescens, Salix arctica, or Ranunculus sulphureus. It is thus clear that they must be wet for a substantial period each year. They were, in fact, still wet in mid August 1962, despite negligible rainfall; and, despite a late start, all the major species matured seed freely. The slopes dry out too much to sustain Eriophorum scheuchzeri and some other marsh species, but the summer flooding also excludes various mesophytes. The occurrence of an Eriophorum on slopes of 15 to 30 per cent grade is unusual. If Sphagnum occurred in Ellesmere Island, these slopes would presumably be transformed into hillside bogs such as are seen on the wet west slopes of the Queen Charlotte Islands.

The springy slope at 750 to $850 \mathrm{~m}$. on the north face of Mt. McGill (E 1) deserves special mention. It is a cirque in which the snow lies later than on the south face, and it combines the characters of talus and springy slope. It remains wet all summer. Several moist-mesophytes occur here to $850 \mathrm{~m}$., where they are evidently stopped only by increasing aridity. At 820 to 850 $\mathrm{m}$., in addition to the species recorded under boulder talus from $900 \mathrm{~m}$., the following are abundant: Luzula confusa, L. nivalis, Cerastium beeringianum, Cardamine bellidifolia, Saxifraga nivalis, and S. tenuis; S. rivularis occurs sparingly. Most of these species were well beyond first anthesis on July 5 . These observations suggest that temperature conditions on this north slope at $820 \mathrm{~m}$. are more favorable than those for any exposure at sea-level at Isachsen (Savile 1961), where the July mean is $38^{\circ} \mathrm{F}$. $\left(3.3^{\circ} \mathrm{C}\right.$.); and that only a lack of diversity in habitats prevents the occurrence of a much larger flora. Several of the bryophytes listed under talus slopes were found to be plentiful on this site.

\section{Marshes and sedge meadows}

Like most of the springy slopes almost all marshes are subject to a marked fluctuation in water-level. They are wet briefly during snow melt, but the water-table then recedes and most of the marsh area becomes progressively drier until early July, by which time many of the small creeks disappear before reaching Lake Hazen.

"Skeleton Creek" is apparently permanent from pond 34 (F 9), through the adjacent ponds 35 and 36 , and down a marshy valley to the first exten- 
sive marsh ( $\mathrm{J}$ 8), where it disappeared in 1962. During the second week of July increasing flow of the creek gradually revived the marshes, but some peripheral areas never became thoroughly reflooded. In 1961 and 1963 drying was much less severe, but it is clear that the fluctuation in waterlevel is always substantial.

This fluctuation not only affects the time of flowering of plants in the marshes, but also markedly governs the species that can survive in them. By far the richest marshy sites in the study area are the outlet of pond 34 (F 9) and a steep slope below the outlet of pond 36 (G 8). Although slight changes in water-level occurred at these sites, they were never devoid of free water even in 1962. Here were found Juncus albescens, J. castaneus, Lychnis apetala, Eutrema edwardsii, Cardamine pratensis, Saxifraga foliolosa, S. hirculus var. propinqua, and Epilobium davuricum var. arcticum, which were scarce or absent elsewhere, as well as various species of more general distribution. The principal mosses at the water-level in the marshy border are Bryum teres, Cinclidium latifolium, and Drepanocladus brevifolius; the last named is also important as a bottom plant in this and other ponds. The hummocks, generally 10 to $15 \mathrm{~cm}$. high, are composed chiefly of Pohlia nutans, Leptobryum pyriforme, Aulacomnium turgidum, and Tomenthypnum nitens.

The intermittently dry areas often yielded little but the dominant Carex aquatilis var. stans, sometimes with one or more of the following: Eriophorum triste (on slopes), E. scheuchzeri (in slight depressions with nearly stagnant standing water during at least part of the summer), Carex misandra, C. amblyorhyncha (on moss hummocks), C. miliaris, traces of a few mesophytes, and rarely traces of one or two of the scarcer marsh plants listed above. Arctagrostis latifolia is often abundant at pond edges and in marshes without excessive fluctuation in water-level. C. aquatilis var. stans dominates all marshes and sedge meadows in the district. It is very variable in stature (mainly a reflection of water supply), ranging from 5 to $7 \mathrm{~cm}$. on the highest sites to $68 \mathrm{~cm}$. in the richest ponds. Its marked clonal (genetic) variation in size and color of scales and in size and shape of perigynia raises the problem of intergradation with $C$. bigelowii. The above name is used provisionally for the whole complex.

\section{General conclusions}

The Hazen Camp area and similar sites along the northwest shore of Lake Hazen clearly have a larger flora than many sites as much as $8^{\circ}$ farther south and, apparently, a larger insect fauna. The biotic richness is mainly due to favorable summer temperatures. Air invading the valley deposits most of its moisture in the surrounding mountains and icefields, absorbs the latent heat of condensation and freezing, and, descending to the lake, is further warmed by compression. Thus it reaches lake-level substantially warmer that it was when it left sea-level. Low wind velocity encourages stratification of air near the ground, allowing that adjacent to the ground to become unusually warm. Clouds are mostly thin cirrus and 
altocumulus or altostratus, which allow substantial light to reach and warm the ground. This is in sharp contrast to some coastal stations such as Isachsen, where two or three heavy stratus decks often occur below the high and middle cloud.

The full picture of the temperature regime near Lake Hazen cannot yet be presented. Although it has been suggested earlier in this paper that the lake appreciably cools the adjacent land in summer, the proximity of sharply rising ground behind Hazen Camp complicates the assessment of this effect, and transportation problems have made it impracticable to secure temperature records on the plateau across the lake. On the south slopes of Mt. McGill it is difficult to distinguish the effects of air temperature and of enhanced insolation, particularly in spring. Yet the good growth in the north-facing cirque, devoid of spring sunshine, shows that the air temperature here in summer is higher than would be expected for this altitude if the temperature in the screen at the camp were truly representative. It is thought that the mean summer depression at the camp may amount to nearly $2^{\circ} \mathrm{F}$. ( $1^{\circ} \mathrm{C}$.). The floristic and phenological data from Mt. McGill are inadequate because aridity is a disturbing factor near the summit; but on a shoulder at $910 \mathrm{~m}$. plants were fully as large as and matured earlier than the same species at Isachsen, where the July mean is $38^{\circ} \mathrm{F}$. Using a conservative lapse rate for moist air of $3.0^{\circ} \mathrm{F}$. per 1000 feet, a temperature of $38^{\circ} \mathrm{F}$. on this shoulder would be equivalent to $45^{\circ}$ at lake level.

The Hazen Camp area lacks mountain peaks high enough to indicate the limits of plant growth. Powell (1961) recorded 35 species of vascular plants at or above $1060 \mathrm{~m}$. on nunataks at the Gilman Glacier, where cooling from the glacier would be as severe as cooling from the lake at Hazen Camp. This number of species suggests either a mean July temperature of about $37^{\circ} \mathrm{F}$. or an unusually long effective growing period. G. Hattersley-Smith (pers. comm.) reports Papaver radicatum, an exceptionally cold-tolerant species, flowering at up to $1460 \mathrm{~m}$. in the same area on a southwest slope with the protective mass of the high icefield behind it.

The aridity of Hazen Camp is as striking as its high summer temperature. But for the streams emerging from the talus slope the flora would be much smaller than it is. The rolling ground southeast of the lake harbours mainly a sparse covering of xerophytes or facultative xerophytes, among which tap-rooted species such as Oxyria digyna, Lychnis triflora and Erysimum pallasii predominate.

The general aridity causes Alopecurus alpinus and Papaver radicatum to be much less abundant than in moister regions, but both make excellent growth on well-watered sites.

A further indication of the light rainfall is the extreme scarcity of the conspicuous moss Rhacomitrium lanuginosum, which commonly clothes rocky slopes and hilltops in moister regions. Other mosses are also extremely scarce except on wet slopes and in marshes and small streams. Crustose lichens on the rocks of Mt. McGill are very scarce and poorly developed in contrast with the situation in moister regions. 
Various grasses achieve a remarkably luxuriant growth on southwest slopes that are not too arid. Many plants are far beyond the $42 \mathrm{~cm}$. height that permits them to be pressed without folding.

The effect of aridity in restricting the occurrence of some parasitic fungi is discussed by Savile and Parmelee (1964). Some saprophytic microfungi that are ubiquitous in wetter parts of the arctic also are scarce or absent at Hazen Camp. Moreover, although various other fleshy fungi were abundant in 1962 in wet habitats, upland species such as Agaricus arvensis and Calvatia cretacea, which are plentiful in some seasons, failed to fruit in 1962, all specimens found being from previous years. One group of the latter consisted of three sporocarps apparently dating from 1959, 1960 and 1961.

As is generally true in the High Arctic, nitrification is slight on upland sites. It is worth noting that immediately adjacent to the camp site, which has been occupied at least briefly each year since 1957, growth is in places abnormally lush. This is particularly true in a depression immediately north of the camp rise where moisture is adequate. This effect is attributable to seepage both from the garbage pit and of urine. Nitrification is particularly evident in a colony of Salix arctica, which was extremely heavily rusted by Melampsora epitea; and in one of Puccinellia angustata, heavily attacked by the powdery mildew Erysiphe graminis, which seldom infects this species. On arid sites the supply of nitrogen is of little significance, for the lack of water limits growth.

\section{Phenological records, 1962}

Table 1 gives first flowering dates in the lowlands near Hazen Camp for common species most of which are readily recognized. No dates for species on the talus slope are included because the dates are not comparable with those from the lowlands; it is also impossible to climb the mountain

Table 1. Phenological records from lowlands adjacent to Hazen Camp in 1962.

\begin{tabular}{|c|c|c|c|c|c|}
\hline \multirow[b]{2}{*}{ Saxifraga oppositifolia } & \multicolumn{2}{|c|}{$\begin{array}{l}\text { Date of } \\
\text { incipient } \\
\text { flowering }\end{array}$} & \multirow[t]{2}{*}{ Species } & \multicolumn{2}{|c|}{$\begin{array}{l}\text { Date of } \\
\text { incipient } \\
\text { flowering }\end{array}$} \\
\hline & June & 7 & & June & 20 \\
\hline Lesquerella arctica & June & 7 & Papaver radicatum & June & 20 \\
\hline Salix arctica & June & 13 & Carex rupestris & June & 20 \\
\hline Dryas integrifolia & June & 15 & Arenaria rubella & June & 20 \\
\hline Erigeron compositus & June & 16 & Cerastium aipinum & June & 20 \\
\hline Oxyria digyna & June & 17 & Saxifraga tricuspidata & June & 22 \\
\hline Erysimum pallasii & June & 17 & Pedicularis capitata & June & 24 \\
\hline Potentilla chamissonis & June & 17 & Saxifraga hirculus & July & 4 \\
\hline Eriophorum triste & June & 18 & Trisetum spicatum & July & 6 \\
\hline Cassiope tetragona & June & 18 & Poa hartzii & July & 10 \\
\hline Stellaria edwardsii & June & 18 & Agropyron latiglume & July & 16 \\
\hline Taraxacum arctogenum & June & 19 & Festuca brachyphylla & July & 16 \\
\hline Taraxacum pumilum & June & 20 & Salix arctica (incipient & July & 28 \\
\hline Pedicularis arctica & June & 20 & capsule dehiscence) & & \\
\hline
\end{tabular}


slopes frequently enough to secure reliable data. As noted above, Saxifraga oppositifolia was found in flower on the Ruggles River on June 2. Lateseason markers are scarce, hence inclusion of incipient capsule dehiscence in Salix arctica.

Because 1962 was unusually warm in both spring and summer, it is not possible to estimate average flowering dates for the camp area. Presumably most species generally flower several days later. However, most species seem to have produced mature seed in the cool season of 1961, to judge from the appearance of the overwintered plants in 1962. One contrast may be noted. The 1961 seeds of Dryas integrifolia were just starting to shed on June 16, 1962. The 1962 seeds reached the same stage on about August 5, 1962. By August 7 the seed shedding of Dryas, Eriophorum scheuchzeri and $E$. triste was clearly more advanced than that of the 1961 seed on June 16.

\section{Annotated list of vascular plants}

Powell (1961) published a provisional list of plants for essentially the whole length of the northwest shore of Lake Hazen, but without specific localities. His allocation of the plants to Raunkiaer's rather arbitrary lifeforms provides little ecological information. In the present list notes on habitat and abundance are accordingly included. A report by Oliver and Corbet will give further data on the occurrence of various aquatic and paludal species in or about specific ponds. Powell's list contains some species that have not been seen at or near Hazen Camp; and a few species collected near Hazen Camp are not recorded by Powell. All the species listed below were taken within the area covered by Fig. 2. The genus Draba, together with some other Cruciferae, is under cytotaxonomic study by G. A. Mulligan; the Draba list is partly provisional and perhaps incomplete. No attempt is made here to separate the elements of the Poa arctica complex, some of which are difficult to place in existing treatments. In other respects the list is thought to be complete for the camp area. It appears that the total for the Lake Hazen basin may be about 115 species.

It has been possible to secure seed germination from about one third of the species listed. Dr. T. Mosquin and Mr. G. A. Mulligan will report elsewhere on the cytological data.

It may be pointed out that the Lake Hazen area supports essentially the whole flora of Peary Land and some additional species from the south or southwest. Many plants that must have been generally distributed during the postglacial hypsithermal (xerothermic) are, in the High Arctic, now localized in fiords or valleys with benign summer climates. Lake Hazen is perhaps the outstanding example of such a posthypsithermal refugium.

EQUISETUM ARVENSE L. Widespread on moist sandy soil of beaches, deltas and hillsides. Fruited more freely than is general in the Arctic.

EQUISETUM VARIEGATUM Schleich. Widespread in moist areas, generally on sites richer in humus than those occupied by $E$. arvense.

CYSTOPTERIS FRAGILIS (L.) Bernh. (s. lat.). Scarce in deep crevices of southeast boulder talus at $600 \mathrm{~m}$. 
WOODSIA GLABELLA R. Br. Occasional on relatively dry east or southeast talus at 450 to $600 \mathrm{~m}$.

AGROPYRON LATIGLUME (Scribn. \& Sm.) Rydb. Localized on a few south or southwest slopes of sandy clay, but tall and abundant in these sites (E 12, N 8).

ALOPECURUS ALPINUS J. E. Sm. Most frequent on moist talus slopes at 450 to $600 \mathrm{~m}$., but also common along lowland stream banks. Absent from dry sites.

ARCTAGROSTIS LATIFOLIA (R. Br.) Griseb. Abundant in peripheral parts of marshes and pond margins with shallow standing water, but not where extreme drying of the soil occurs. Well grown on some springy slopes to $450 \mathrm{~m}$.

CALAMAGROSTIS PURPURASCENS R. Br. Locally abundant in muddy sand on south or southwest slopes of Blister Hill (E 11) and at a fox den beyond western limits of Fig. 2. sand.

COLPODIUM VAHLIANUM (Liebm.) Nevski. Occasional on wet, muddy delta

DESCHAMPSIA BREVIFOLIA R. Br. Scarce on moist muddy delta.

FESTUCA BAFFINENSIS Polunin. Occasional on moss hummocks by ponds, on Dryas tundra, or along a sandy watercourse.

FESTUCA BRACHYPHYLLA Schultes. Occasional along brooks, clay slopes, or sandy watercourse. All material seems referable to this species rather than $F$. hyperborea Holmen; plants were secured from only one of three seed samples, and for this specimen Dr. Mosquin secured a chromosome count of $2 n=42$, confirming the identification.

PHIPPSIA ALGIDA (Sol.) R. Br. Localized in a sandy, intermittently flooded area by the lake (pond 41 ).

PHIPPSIA CONCINNA (Th. Fries) Lindeb. Rare in wet moss on north slope at $820 \mathrm{~m}$. (E 1).

PLEUROPOGON SABINEI R. Br. Abundant in shallow parts of pond 10, but fruiting sparsely; also in pond 21C. Very rare elsewhere, partly because of fluctuating water-levels in marshes.

POA ABBREviATA R. Br. Abundant on moist muddy sand of delta (G 16) and scattered on talus slope at 450 to $600 \mathrm{~m}$. Absent from dry lowland sites.

POA ARCTICA R. Br. (s. lat.). Widespread in moist lowland gullies and on springy slopes to $790 \mathrm{~m}$.

POA GLAUCA M. Vahl. Common on dry muddy or gravelly banks and to $670 \mathrm{~m}$. on talus slope.

POA HARTZII Gand. Abundant on muddy or gravelly banks; occasionally in moister gullies where leaves may be green and flat (as they are when the plant is grown in a moist greenhouse).

POA HARTZII Gand. $\times$ P. GLAUCA M. Vahl. Intermediates range from nearly typical hartzii to nearly typical glauca, indicating substantial introgression. This capacity for hybridization partly explains the various chromosome counts reported for both species (Holmen 1952, p. 35). See also Savile and Parmelee (1964) for discussion of a rust that attacks hartzii and the hybrid but not glauca.

PUCCINELLIA ANGUSTATA (R. Br.) Rand \& Redf. Common on saline clay flats and shallow depressions. Occasional on scarcely saline slopes where, if depauperate, it simulated $P$. bruggemanni, which, however, seems to be absent from the area.

PUCCINELLIA POACEA Th. Sør. Tall and abundant on a shallowly sloping saline clay plain (N 7), where it grew in the centres of the polygons whereas $P$. angustata grew in the cracks.

TRISETUM SPICATUM (L.) Richt. Occasional in sand or sandy mud, rarely in wet moss, on southeast to southwest slopes.

ERIOPHORUM SCHEUCHZERI Hoppe. Abundant in shallow standing water and permanently wet marshes; never on springy slopes.

ERIOPHORUM TRISTE (Th. Fries) Hadač \& Löve. Abundant in flowing marshes and on springy slopes to $520 \mathrm{~m}$., including some that dried out markedly in early summer. 
KOBRESIA MYOSUROIDES (Vill.) Fiori \& Paol. Very abundant with Dryas integrifolia on steep to gentle slopes, often down to the margins of marshes; up to ca. $550 \mathrm{~m}$. on talus slopes.

CAREX AMBLYORHYNCA Krecz. Occasional on moss hummocks in marshes.

CAREX AQUATILIS Wahlenb var. STANS (Drej.) Boott. Dominant in all marshes, sometimes fruiting freely, sometimes very sparsely without obvious reason, and up to $68 \mathrm{~cm}$. tall in enriched ponds; also at pond or marsh borders, in moist meadows and on moist delta deposits, where much shorter but generally in good fruit. See discussion under marshes.

CAREX ATROFUSCA Schk. Occasional on moss hummocks or in higher parts of marshes.

CAREX CAPILLARIS L. Widespread but never abundant in moist areas from the lake shore to $370 \mathrm{~m}$.

CAREX MARITIMA Gunn. On loose sand at $320 \mathrm{~m}$. on Blister Hill, also in moist mossy depressions with, e.g., Eriophorum scheuchzeri, and on a springy slope at $450 \mathrm{~m}$. with E. triste. Only in the Yukon Territory has this species of coastal dunes been reported in such varied inland habitats.

CAREX MILIARIS Michx. Occasional in shallow or intermittently wet marshes.

CAREX MISANDRA R. Br. Moderately common on wet slopes and depressions, up to $370 \mathrm{~m}$.

CAREX NARDINA Fries. Common on Dryas slopes and dry talus slopes up to $730 \mathrm{~m}$.

CAREX RUPESTRIS All. Occasional on dry Dryas tundra and on lower talus slopes to ca. $485 \mathrm{~m}$.

JUNCUS ALBESCENS (Lange) Fern. Scattered on a marshy gentle slope (F 9).

JUNCUS BIGLUMIS L. Moderately common in wet mossy, muddy or rarely sandy situations.

JUNCUS CASTANEUS J. E. Sm. Scarce in marsh with constant water-table (G 8).

LUZULA CONFUSA Lindeb. Common on moderately dry slopes up to $820 \mathrm{~m}$, or sandy watercourses wet in spring.

LUZULA NIVALIS (Laest). Beurl. Rare in sandy watercourse. Common on moderately wet slopes to at least $800 \mathrm{~m}$. where limited only by moisture requirements.

SALIX ARCTICA Pall. Frequent on talus slopes to $700 \mathrm{~m}$. and on muddy south slopes, level tundra, sedge meadows, and creek banks. Occasional in depressions behind beach ridges, where leaves small and annual growth very short, apparently because prolonged immersion in years of high water, such as 1958 and 1962, kills most of the roots. Intergradation with normal plants on higher ground indicates the difference to be phenotypic, although genetic variants of this plastic species also occur.

OXYRIA DIGYNA (L.) Hill. Abundant on dry or wet sand or clay and on talus slopes up to $760 \mathrm{~m}$. In nearly full fruit on south slope at $760 \mathrm{~m}$. on June $29,1962$.

POLYGONUM VIVIPARUM L. Common only in moist situations up to $760 \mathrm{~m}$.

ARENARIA ROSSII R. Br. Scarce in moist sites up to $360 \mathrm{~m}$.

ARENARIA RUBELLA (Wahlenb.) J. E. Sm. Moderately common in moderately dry sandy, gravelly or stony situations up to at least $600 \mathrm{~m}$.

CERASTIUM ALPINUM L. Moderately common on talus slope at 450 to $550 \mathrm{~m}$. Occasional in lowlands including Blister Creek delta where, on July 13 in adjacent plants in identical habitats, this species was in full flower, $C$. beeringianum was nearly past flowering and C. arcticum was in nearly full fruit.

CERASTIUM ARCTICUM Lange. Moderately common on talus slope at 600 to 760 m. Occasional on delta (see C. alpinum).

CERASTIUM BEERINGIANUM Cham. \& Schlecht. Moderately common on moist mossy slopes and in higher parts of marshes; occasional on moist delta silt (see $C$. alpinum). Noted on north slope up to $790 \mathrm{~m}$.

LYCHNIS APETALA L. var. ARCTICA (Fries) Cody. Occasional on springy slopes 
and wet talus to $600 \mathrm{~m}$. Occasional in a few marshes with nearly constant water-tables. Much less abundant than in moister arctic areas with comparable temperatures.

LYCHNIS TRIFLORA R. Br. Abundant on steep or gentle south slopes ranging from muddy sand to nearly pure clay. Although great variation in stature and petal colour of this species makes it difficult to be certain, L. affinis J. Vahl ex Fries seems to be absent from the study area.

SILENE ACAULIS L. var. EXSCAPA (All.) DC. Rare on east and northeast slopes at 450 to $600 \mathrm{~m}$.

STELLARIA CRASSIPES Hult. Moderately common on moist stony or muddy creek banks. One specimen appears to approach $S$. monantha.

STELLARIA EDWARDSII R. Br. (S. ciliatosepala Trautv.). Abundant on south and southwest muddy creek banks; tall plants grew on moss hummocks in marsh.

STELLARIA LAETA Richards. Moderately common on southwest muddy creek banks, scattered in sand at $300 \mathrm{~m}$. on east face of Blister Hill, scattered on southeast talus slope up to $600 \mathrm{~m}$.

STELLARIA EDWARDSII R. Br. $\times$ S. LAETA Richards. Two collections were referable to this hybrid; one from the bank of "Skeleton Creek" where both parents were collected (N 8), and one from an isolated gravel knoll. Since the latter collection is relatively uniform it may have been from a clonal colony.

STELLARIA MONANTHA Hult. Scattered on talus slopes up to $670 \mathrm{~m}$. The similarity of these four species makes it difficult to distinguish them in the field. Thus it is not easy to compare their ecology and local distribution accurately or to assess the amount of hybridization. Porsild (1963) has recently discussed this complex and records some hybrids. He is inclined to regard the populations as subspecies; but, because of the vast common ranges within which most specimens are clearly assignable to one of the taxa involved, this does not seem to be an appropriate solution. They seem to be species with incomplete genetic barriers. They presumably differentiated in Pleistocene refugia, but, because the seeds and plants disperse so rapidly over the hard winter snow surface, it is difficult to identify the refugia. S. crassipes may be derived from Peary Land.

RANUNCULUS HYPERBOREUS Rottb. Locally abundant on wet mud and in moss at pond margins.

RANUNCULUS SULPHUREUS Sol. Occasional on springy mountain slopes at 250 to $820 \mathrm{~m}$.

RANUNCULUS TRICHOPHYLLUS Chaix var. ERADICATUS (Laest.) W. B. Drew. Occasional in mud or moss in shallow ponds $(1,10,32$, at P11, N6 and G9 respectively). In pond 32 , where the water-level rose during the summer, it flowered and fruited almost exclusively below the surface.

PAPAVER RADICATUM Rottb. (s. lat.). The form with white petals and yellow claws was seen sparingly between 760 and $910 \mathrm{~m}$. The typical yellow-petalled form occurred from lake-level to over $920 \mathrm{~m}$., its height being related to moisture supply rather than altitude, as is to be expected in this cold-tolerant species (Savile 1959). Owing to the extremely low summer precipitation, this species is much scarcer in the Lake Hazen lowlands than in most parts of the archipelago.

BRAYA HUMILIS (C. A. Mey.) Robins. Common especially on south-facing banks of sandy mud.

BRAYA PURPURASCENS (R. Br.) Bunge. Common, often with B. humilis.

BRAYA THORILD-WULFFII Ostenf. Widespread but never abundant on south and southwest slopes, usually on sandy soil.

CARDAMINE BELLIDIFOLIA L. Common on springy slopes and along brooks at 450 to $820 \mathrm{~m}$., where checked only by aridity.

CARDAMINE PRATENSIS L. var. ANGUSTIFOLIA Hook. Scattered in marshes with little fluctuation in water-level; purely vegetative.

COCHLEARIA OFFICINALIS L. (s. lat.). A single plant was found on wet silt 
of Blister Creek delta. Apparently not previously recorded from the interior of northern Ellesmere Island. Seed possibly brought in by birds (e.g., Greater Snow Goose), but more probably brought down by flood water from solifluction slopes or other disturbed soil on which the species tends to become established.

DRABA BELLII Holm. Occasional in sand blowout (L 11), but also on relatively dry talus slopes up to $750 \mathrm{~m}$.

DRABA CINEREA Adams. Occasional on south clay banks and on talus slope to $750 \mathrm{~m}$.

DRABA GROENLANDICA El. Ekman. Scattered on south earth banks and talus slopes to ca. $600 \mathrm{~m}$.

DRABA LACTEA Adams. Moderately common in wet moss along springy slopes. Absent from lowland marshes.

DRABA OBLONGATA R. Br. Occasional by cold brooks.

DRABA SUBCAPITATA Simm. Scarce on moist talus slopes at 600 to $750 \mathrm{~m}$.

ERYSIMUM PALLASII (Pursh) Fern. Abundant on dry mud or gravel hillocks and south slopes. Occasional on dry talus slopes to ca. $600 \mathrm{~m}$.

EUTREMA EDWARDSII R. Br. Occasional on wet talus slopes at 365 to $425 \mathrm{~m}$., and in the marshy borders of lowland ponds with stable water-levels.

LESQUERELLA ARCTICA (Wormskj.) S. Wats. Abundant on dry south slopes in gravelly or sandy soil. Occasional on clay flats.

SAXIFRAGA CAESPITOSA L. Abundant on moist slopes from 550 to $910 \mathrm{~m}$. On favorable sites scapes are tall, 1- to 2-flowered and with little anthocyanin, approaching the phenotypic expression of low-arctic specimens.

SAXIFRAGA CERNUA L. Common along brooks and on moist slopes from 550 to $910 \mathrm{~m}$., in favorable sites up to $23 \mathrm{~cm}$. high.

SAXIFRAGA FLAGELLARIS Willd. ssp. PLATYSEPALA (Trautv.) Porsild. Occasional on moderately dry earthy slopes at 600 to $720 \mathrm{~m}$. Not in lowlands.

SAXIFRAGA FOLIOLOSA R. Br. Rare in moss of permanently wet marshes or along brooks.

SAXIFRAGA HIRCULUS L. var. PROPINQUA (R. Br.) Simm. Occasional in marshy areas with stable water-level.

SAXIFRAGA NIVALIS L. A single large plant was seen on a hummock in a brook at the talus foot. Otherwise scattered between 760 and $910 \mathrm{~m}$.

SAXIFRAGA OPPOSITIFOLIA L. Common from lake-level to $910 \mathrm{~m}$. Occurs in many genetic forms of varying petal shape and colour, in contrast to Isachsen where only two forms occurred. In some colonies it was almost impossible to find two plants that matched exactly. The situation suggests that the two species of bumble-bees (Megabombus polaris and M. hyperboreus) that occur at Hazen camp achieve an appreciable amount of cross-pollination. Marked and colour-photographed plants were collected in fruit; but all were small owing to the extreme aridity, seed set was sparse and germination has been poor. Thus there is no immediate prospect of a successful cytogenetic study of the complex. Large clonal colonies, $30 \mathrm{~cm}$. or more in diameter, such as may be found in moister arctic regions, do not occur at Hazen Camp where most plants are about 3 to $8 \mathrm{~cm}$. across.

SAXIFRAGA RIVULARIS L. (s. lat.). Rare on north slope at 760 to $820 \mathrm{~m}$.

SAXIFRAGA TENUIS (Wahlenb.) H. Sm. Abundant in small area on wet north slope at 760 to $850 \mathrm{~m}$., but elsewhere rare and above $750 \mathrm{~m}$. only.

SAXIFRAGA TRICUSPIDATA Rottb. Moderately common on rocky and gravelly slopes in lowlands. Common on dry talus slopes above $450 \mathrm{~m}$. and sparingly to $850 \mathrm{~m}$. Mostly f. tricuspidata, but a few plants referable to f. subintegrifolia (Abrom.) Polunin were seen in one colony.

POTENTILLA CHAMISSONIS Hult. Abundant on clay polygons and south or southwest clay, gravel or sandy mud slopes. Best developed on slightly moist, grassy south slopes. One of the most conspicuous plants on south-facing banks, and apparently 
a major source of nectar. I follow Holmen (1957) in the interpretation of this species, rather than Porsild (1957) who includes some material with digitate basal leaves in $P$. rubricaulis. In arid situations the aspect of these plants is greatly modified, partly because, although the number of hairs per leaf seems to remain nearly constant, aridity may reduce the leaves to one half the normal diameter, i.e., one quarter the surface area, so that pubescence density is correspondingly increased.

POTENTILLA HYPARCTICA Malte. Completely absent from the lowlands, but occurring sparingly on moderately dry talus slopes, at $550 \mathrm{~m}$. on a northeast slope and 600 to 760 on a southeast slope. Although Holmen (1957) speaks of this species as growing on dry ground in Peary Land, it should be noted that he found it absent from "decidedly continental areas". It is certainly severely restricted by aridity at Hazen Camp in contrast to its ubiquitous occurrence in more humid regions.

POTENTILLA PULCHELLA R. Br. Uncommon; found on two sites on south slopes of sandy mud on Blister Hill.

POTENTILLA RUBRICAULIS Lehm. Occurred sparingly on clay polygons with P. chamissonis. Because it may simulate that species its exact status cannot be stated as precisely as that of the remaining, more distinctive species, but it must be considered scarce in the area.

POTENTILLA VAHLIANA Lehm. Scarce, on a gravelly slope in the foothills north of camp.

DRYAS INTEGRIFOLIA M. Vahl. The dominant plant of mesic and moderately arid sites, and ecologically the most important plant in the area, both for its physical effect on the soil and as a food source. It is especially important as a source of nectar for a wide range of insects. Holmen (1957) refers most of the Peary Land material to $D$. chamissonis Spreng. ex Juz. on the basis of the leaf margins. Much the same range of variation that Holmen illustrates may be seen in many parts of the Canadian Arctic Archipelago; in particular several specimens from Cornwallis I. have conspicuously dentate leaves. However, none of this material seems actually to be chamissonis; the latter probably does not occur in the archipelago or Greenland. Some marginal toothing is discernible in Hazen Camp specimens, but the margins of most leaves are so strongly revolute in plants on such arid sites that it cannot be readily assessed. However, the leaves seem, on average, to be more nearly entire than those from some sites farther south.

EPILOBIUM DAVURICUM Fisch. var. ARCTICUM (Samuells.) Polunin. Localized in moss on higher parts of marsh with stable water-level (F 9). Rarity due at least in part to the marked fiuctuation of water-level in most marshes. Capsules opening on July 20, in 1962; thus some seed production probable in almost any year.

EPILOBIUM LATIFOLIUM L. Common on delta gravel, and on south talus slopes to $750 \mathrm{~m}$.; occasional on gravelly south slopes.

HIPPURIS VULGARIS L. Abundant but flowering sparsely in water to $45 \mathrm{~cm}$. deep in pond 10, a nearly stagnant pond with nearly constant water-level. Also in pond 78.

CASSIOPE TETRAGONA (L.) D. Don. Abundant on southeast slopes, clothing the sides of Dryas hummocks, but virtually absent from all other situations.

ANDROSACE SEPTENTRIONALIS L. Scarce on sandy slopes and dry, gravelly knolls.

PEDICULARIS ARCTICA R. Br. Abundant on wet to moderately dry sedge meadows and south slopes with essentially closed cover. Corolla rarely white or light pink. This far northern population generally has very small teeth on the galea, which perhaps prompted Porsild (1957) to speak of a form intermediate between arctica and hirsuta. However, at Hazen Camp I could see no suggestion of hybridization between these species although they frequently grew together. Observations on fungal parasites also emphasize their distinctness (Saville and Parmelee 1964). It is suspected that these northern plants may belong to a subspecies originating in Peary Land. It probably penetrates typical arctica to some degree without complete intergradation, for these 
northern Pedicularis almost certainly self-pollinate when bumble-bees are scarce or inactive (Savile 1959, p. 988). The probability is that both populations of arctica are actually subspecies of $P$. langsdorffi Fisch. ex Steven. See also discussion by Porsild (1955).

PEDICULARIS CAPITATA Adams. Common on moderately dry south slopes to over $600 \mathrm{~m}$., and especially with Dryas on shallow slopes at lower altitudes.

PEDICULARIS HIRSUTA L. Common, generally with $P$. arctica but less abundant. Corolla very rarely white.

PEDICULARIS SUDETICA Willd. Discovered by B. Hocking in 1963 at pond 17 (A 16). Evidently prevented from flowering 1962 by low water, for I could scarcely have failed to note the dark corollas and subscapose stems when checking this pond in July of that year. Apparently not previously recorded north of Eureka.

ARNICA ALPINA (L.) Olin ssp. ANGUSTIFOLIA (Vahl in Hornem.) Maguire. Occasional on southeast talus slope at 450 to $600 \mathrm{~m}$., mainly in two colonies. A few, generally vegetative plants on south and southwest slopes of Mt. McGill where talus generally drier and less stable than on southeast slopes.

ERIGERON COMPOSITUS Pursh var. DISCOIDEUS Gray. Abundant on dry, generally south-facing banks, usually in heavy soil. Rays generally tinged with purple in age.

ERIGERON ERIOCEPHALUS J. Vahl. Occasional on moist talus at 600 to $760 \mathrm{~m}$.

TARAXACUM ARCTOGENUM Dahlst. Abundant on south slopes and cut banks; by far the commonest member of the genus. This close relative of the more southern T. lacerum is now known in arctic Canada from Lake Hazen, Eureka, and western Axel Heiberg Island.

TARAXACUM HYPARCTICUM Dahlst. Occasional at $750 \mathrm{~m}$. on southeast talus slope.

TARAXACUM PHYMATOCARPUM J. Vahl. Occasional on muddy south slopes of Blister Hill.

TARAXACUM PUMILUM Dahlst. Occasional in the same habitat at T. phymatocarpum.

\section{Acknowledgements}

I am indebted to Dr. W. C. Steere, New York Botanical Garden, for the identification of all bryophytes collected at Hazen Camp; and to Drs. P. S. Corbet and D. R. Oliver for abundant advice and assistance in the preparation of this report.

\section{References}

Christie, R. L. 1962. Northeastern Ellesmere Island, District of Franklin. Geol. Surv. Can., Pap. 62-10.

Downes, J. A. 1962. What is an arctic insect? Can. Ent. 94:143-62.

Holmen, K. 1952. Cytological studies in the flora of Peary Land, North Greenland. Medd. Grønl. 128, 5:1-40.

Grøn1. 124, 9:1-149.

Jackson, C. L. 1959. The meteorology of Lake Hazen, N.W.T. I. Analysis of the observations. D. Phys. R. (G). Hazen 8. Def. Res. Board, Ottawa, 194 pp.

Oliver, D. R., and P. S. Corbet. Description of aquatic habitats in the Lake Hazen area, North Ellesmere Island. (In prep.). 


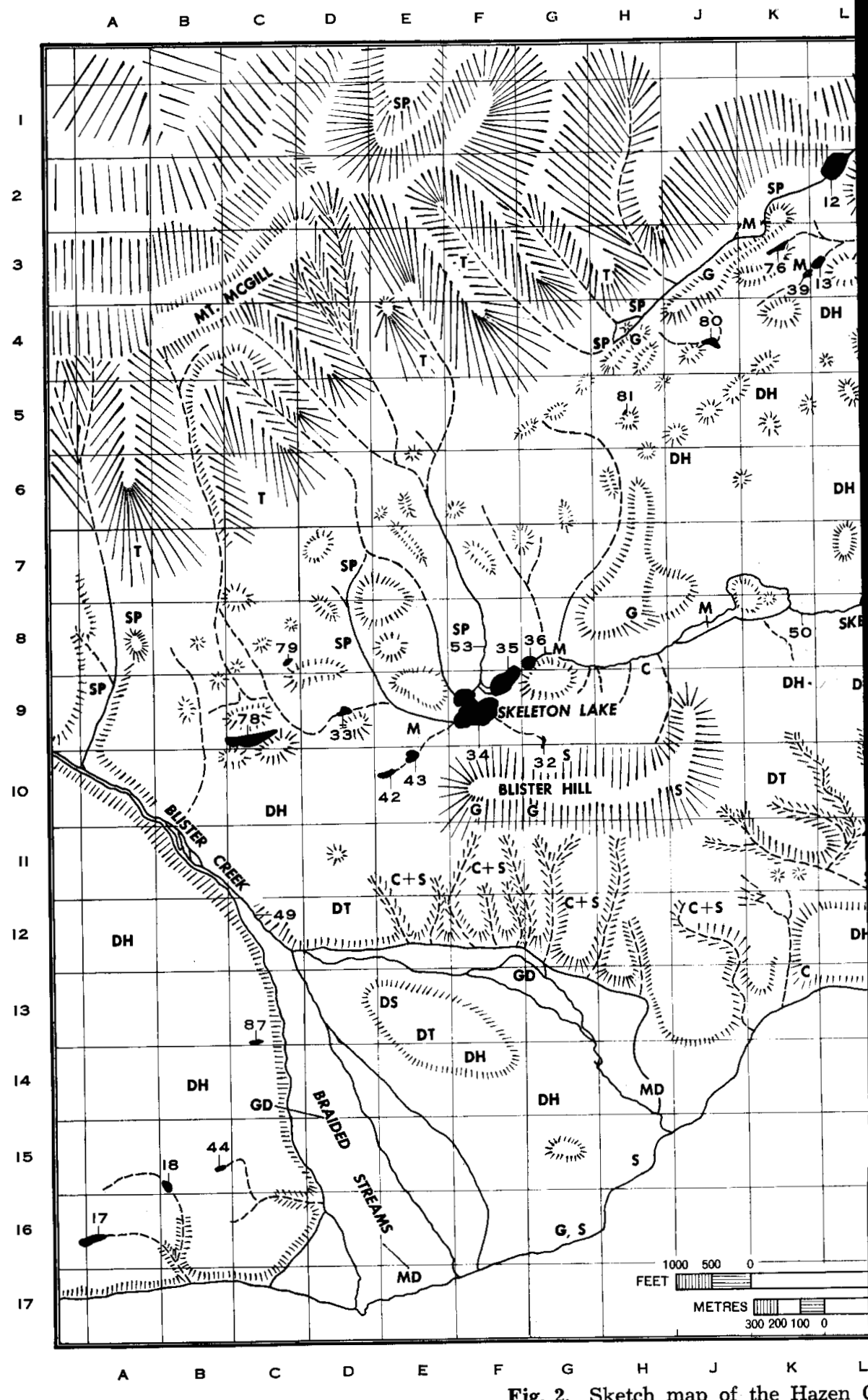

Fig. 2. Sketch map of the Hazen 


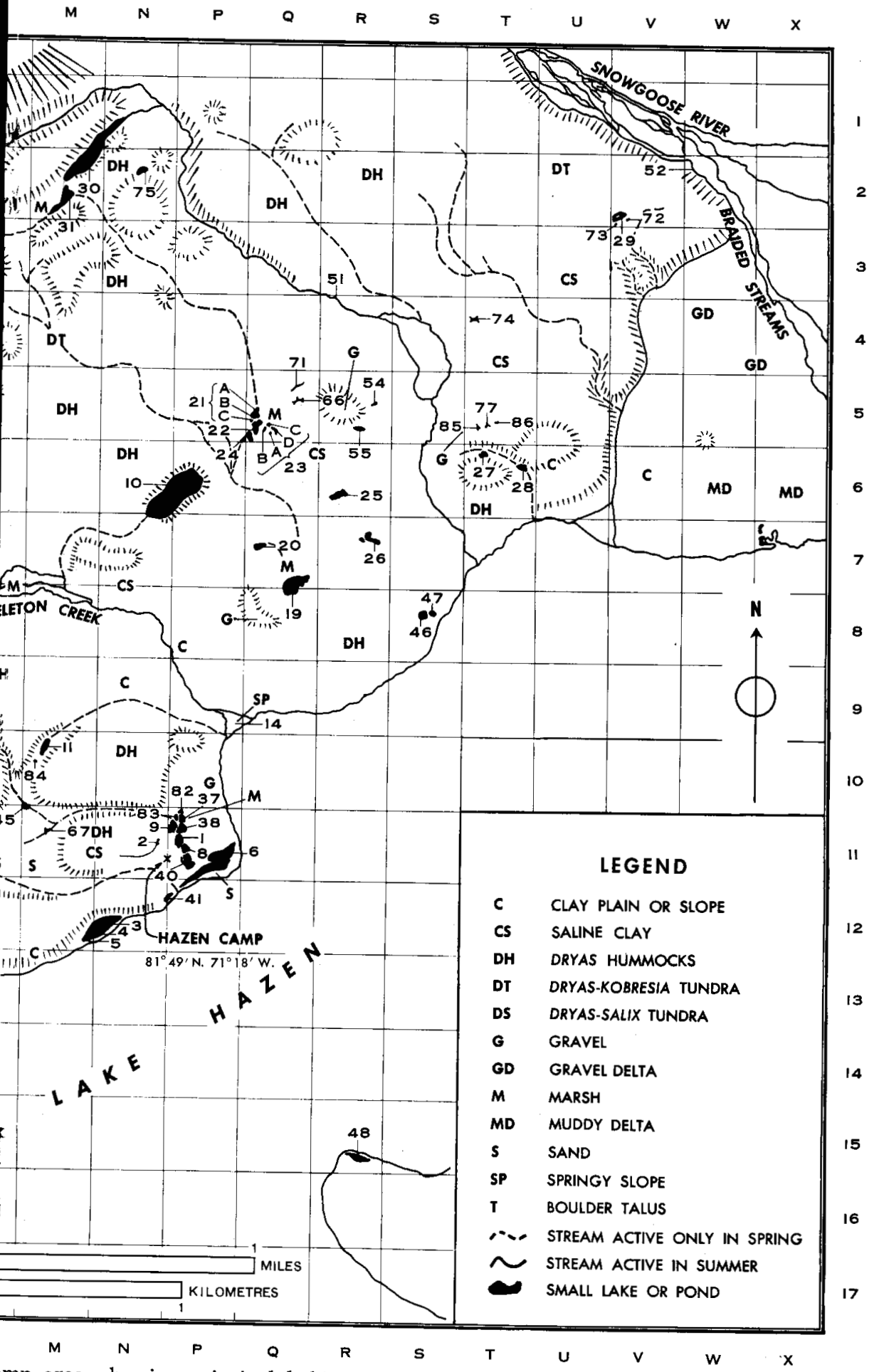

amp area, showing principal habitats. 
Porsild, A. E. 1955. The vascular plants of the western Canadian Arctic Archipelago. Natl. Mus. Can. Bull. 135, 226 pp.

1957. Illustrated flora of the Canadian Arctic Archipelago. Natl. Mus. Can. Bull. 146, 209 pp.

1963. Stellaria longipes Goldie and its allies in North America. Natl. Mus. Can. Bull. 186. pp. 1-35.

Powell, J. M. 1961. The vegetation and micro-climate of the Lake Hazen area, northern Ellesmere Island, N.W.T. D. Phys. R. (G). Hazen 14. Def. Res. Board, Ottawa, 112 pp. Savile, D. B. O. 1959. The botany of Somerset Island, District of Franklin. Can. J. Bot. 37:959-1002.

1960. Limitations of the competitive principle. Science 132:1761.

1961. The botany of the northwestern Queen Elizabeth Islands. Can.

J. Bot. 39:909-42.

1963. Mycology in the Canadian Arctic. Arctic 16:17-25.

Savile, D. B. O., and D. R. Oliver. 1964. Bird and mammal observations at Hazen Camp, northern Ellesmere Island, in 1962. Can. Field Nat. 78:1-7.

Savile, D. B. O., and J. A. Parmelee. 1964. Parasitic fungi of the Queen Elizabeth Islands. Can. J. Bot. 42:699-722. 